\title{
Efficacy of agglutination test in diagnosis of motile Aeromonas septicemia in Nile tilapia (Oreochromis niloticus)
}

\author{
El-Adawy M.M., Ahmed A.A., and Abdel Wahab A.M.
}

Fish Health and Management Department, Central Laboratory for Aquaculture research

Received: Feb. 27, 2018; Accepted: March 29, 2018 Vol.8 (1):1-12

\section{ABSTRACT}

Bacterial diseases are the most common diseases among cultured fish. Aeromonas hydrophila considered the most important freshwater bacterial fish pathogen. Early diagnosis considered the cornerstone in controlling the disease. Biochemical method is laborious, expensive and time consuming whereas agglutination test is simple, rapid, accurate inexpensive and the test can be performed in field conditions. In the present study, agglutination test was established for diagnosis A. hydrophila infection in Oreochromis niloticus. A. hydrophila was isolated from naturally infected fish then distracted to subunits somatic and flagellar antigens. The prepared antigen was reacted with positive antisera of $A$. hydrophila which produced distinct tiny clumps. The sensitivity and specificity of slide agglutination test against collected sera were $90 \%$, $77.5 \%$ respectively in case of somatic antigen and $92.5 \%$, $72.5 \%$ in case of flagellar antigen. It could be concluded that agglutination test can be used as screen test for diagnosis of A.hydrophila infection in fish farms and the method can be diagramed on other bacteria.

Keywords: Aeromonas, agglutination, antigen and Oreochromis niloticus

\section{Introduction}

The advent and anticipation of aquaculture is enhancing food production; more income generation and good health for the people. However, infectious diseases are the most important constraint to aquaculture development and sustainability. Production costs are 
increased through investment lost in dead cultured fish, cost of treatment, and decreased quality and quantity of yields (Idowu et al., 2017). The incidence of microbial pathogens, especially those of bacterial origin is one of the most significant factors affecting fish culture (Zorrilla et al., 2003). Aeromonas hydrophila and other motile aeromonads are the most common bacteria in freshwater habitats throughout the world, (Otte, 1963). Bacterial infections can stem from many causes, even combinations of contributing causes. Infections can be topical (external); fin or tail rot and ulcer diseases, systemic (internal), or both. Stressed fish can be very susceptible to this illness (Idowu et al., 2017). Latex agglutination tests have been applied in many laboratories for the detection of infectious diseases. (Ariel and Owens 1997) firstly described Rheumatoid Factor Test which based on latex agglutination. After that, agglutination test used to detect microbial and viral infections, autoimmune diseases, hormones, drugs and serum proteins have been developed and marketed by many companies worldwide (Post, 1989).

The current study was designed to evaluate the efficacy of agglutination test (slide agglutination and hemagglutination inhibition) as a serological test used in diagnosis of $A$, hydrophila infection in Oreochromis niloticus through preparing colored antigen from locally isolated strain.

\section{Material and methods}

\section{Bacterial isolate}

A. hydrophila strain was previously isolated from clinically diseased fish and biochemically identified in Fish Health and Management Lab. of Central Laboratory for Aquaculture Research (CLAR) according to Austin and Austin (1987). Morphological and biochemical characters of the isolated A. hydrophila were illustrated in table (1).

\section{Fish}

Total numbers of two hundreds of $(50 \pm 5 \mathrm{~g})$ apparently healthy Nile tilapia were obtained from production farm of CLAR. Fish were acclimated to the laboratory conditions for 2 weeks. In well equipped 10 glass aquaria $(80 \times 40 \times 50 \mathrm{~cm})$ filled with dechlorinzed tap water at $25 \pm 1^{\circ} \mathrm{C}$ and continuous aeration using air pumps in the wet laboratory fish were divided into 2 groups (G1, G2). Fish were fed at rate $3 \%$ 
from the biomass and about half of the water was changed with chlorine free water and fecal matters were siphoned out once daily during the experiment. Fish were fed twice daily on standard commercially prepared pellets.

Table (1). Biochemical characters of A. hydrophila used in experimental infection.

\begin{tabular}{lc}
\hline \multicolumn{1}{c}{ Test } & Result \\
\hline Gram stain & Gram -ve Bacilli \\
Tryptic Soya agar & Creamy white colony \\
Aeromonas Base media & Blue green colony \\
Hemolysis & Beta Hemolysis \\
(TSA with 5\% sheep erythrocytes & \\
Ampicillin susceptibility & Resistant \\
Oxidase & $+\mathrm{Ve}$ \\
Oxidation/Fermentation & $+/+$ \\
$\mathrm{H}_{2} \mathrm{~S}$ & Positive \\
Esculin Hydrolysis & Positive \\
Indol & Positive \\
MR & Negative \\
VP & Positive \\
Mannitol fermentation & Positive \\
Sucrose fermentation & Positive \\
\hline
\end{tabular}

\section{Experimental design}

$\mathrm{G} 1$, was injected with $0.5 \mathrm{ml}$ intraperitoneal (I/P) saline containing bacterial isolate (A.hydrophila) as whole bacterial cells $\left(2 \times 10^{6}\right.$ cells $/ \mathrm{ml}$ ) for preparation of hyper immune serum (Luky, 1977). G2 left as control and injected with sterile saline. The fish were observed one week post inoculation for mortalities. The dead fish were removed daily and subjected to bacterial re-isolation to verify death. Blood was collected from all fish groups three times with 7 days interval starting from seventh day without adding anticoagulant for serum separation and evaluating the specific antibody production (Evans et al., 2004).

\section{Hemagglutination inhibition test (HI)}

\section{Evaluation of antibody titer:}

On U shape 96 well microtiter plate $50 \mu \mathrm{PBS}$ was added to all wells, then $50 \mu \mathrm{l}$ of bacterial antigen was added to $1^{\text {st }}$ well and double 
fold serial diluted till the last one. Fifty $\mu \mathrm{l}$ of $0.5 \%$ washed RBCs was added to all wells, mixed by shaking plates, and incubated at room temperature for 30 minutes for measuring the bacterial cut point. The collected serum was serial diluted and tested against the bacterial cut point (McGraw, 1957).

\section{Preparation subunits antigen}

\section{Somatic antigen:}

Bacterial isolate was cultured on to freshly prepared nutrient agar slope, the growth from the slope was washed with saline. Bacterial suspension was boiled in water bath for 10 minutes to destroy the less heat stable and viable antigen (Snieszko, 1976).

\section{Flagellar antigen:}

Formalin $37 \%$ was added at rate of 5 drops $/ 10 \mathrm{ml}$ broth, bacterial cells harvested by centrifugation and resuspended in normal saline (Roberts, 1989).

\section{Slide micro-agglutination test:}

\section{Antigen Staining:}

Tetrazolium blue was added aseptically, $0.5 \%$ to culture. The flask was agitated and incubated for 24 hours. The stained broth suspension was filtered through sterile gauze and poured into eppendorf tubes which were centrifuged at $14,000 \mathrm{rpm}$ for 15 minutes. The supernatant fluid was decanted and the packed cells were suspended in $0.5 \%$ phenol saline. The solution was kept at $4{ }^{\circ} \mathrm{C}$ as tetrazolium-stained antigen (Lowry et al., 1951).

\section{Antibody evaluation:}

The collected serum was examined against stained antigen by slide micro-agglutination test. Twenty $\mu \mathrm{l}$ of stained antigen and $20 \mu \mathrm{l}$ sera were placed on clean, dry porcelain slide and mixed thoroughly. The results were read within 1 min (McGraw (1957).

\section{Estimation of sensitivity and specificity of latex agglutination test}

The analysis was performed according to (Kachigan, 1991). The test was carried out to determine the differences among treated means. Sensitivity was counted by the equitation $A /(A+C) \times 100$, where $A$ is true positive and $\mathrm{C}$ is false negative. Specificity was counted by the equitation $\mathrm{D} /(\mathrm{D}+\mathrm{B}) \times 100$, where $\mathrm{D}$ is true negative and $\mathrm{B}$ is false positive. 


\section{Results and discussion}

Bacteria are responsible for many fatal diseases in fishes. Epidemics of bacterial diseases are common in dense populations of cultured food or aquarium fish. Predisposition to such outbreaks frequently is associated with poor water quality, organic loading of the aquatic environment, handling and transport of fish, marked temperature changes, hypoxia, or other stressful conditions (Idowu et al., 2017).

The used bacterial model in the present study was isolated from diseased fish and biochemically identified in Fish Health and Management Lab. (Table 1). The isolated bacteria was referred to Aeromonas hydrophila according to its biochemical characters which was the same recorded by Austin and Austin (1987). So, the isolated bacteria was used in the present study for preparing of the specific serum and subunit antigens.

Experimentally infected fish showed clinical signs of the disease after 24 hrs. post inoculation of A.hydrophila including inflammatory changes at the site of inoculation, hemorrhages all over body surface, presence of petechial hemorrhages and congestion in liver, kidneys and spleen. Similar results were observed post re-isolation of A.hydrophila from all freshly dead experimentally infected fish. The mortality rate was $60 \%$ Table (2) and Table (3).

HA test is used to standardize antigens for the HI test. Hemagglutination occurs when hemagglutinins on the bacterial antigen interact with receptors on the surface of erythrocytes, and inhibition of HA occurs in the presence of specific antibodies in serum. Wells with complete hemagglutination are recorded as positive, while wells with a distinct button formation are recorded as negative. The endpoint of the titration is the highest dilution of antigen causing complete hemagglutination. The hemagglutinin endpoint was 1/32 and hemagglutinins unit was 32 (Photo 1).

HI test is used to detect and quantitative specific antibodies in serum. Endpoints are reported as the highest serum dilution causing complete inhibition of hemagglutination. The titer was gradually increased following the artificial infection and the highest antibody titer was observed in day 21 post inoculation (Table 4 and Photo 2). Similar findings were described by Sahu et al., (2007). 
The use of subunit flagellar and somatic parts in the antigen is due to protein of this portions are similar with wide range of the $A$. hydrophila serotypes and it is easy to identified at this level that was cited by Evans et al., (2004) who recorded many protein molecules are composed of more than one subunit, where each subunit is a separate polypeptide chain and can form a stable folded structure by itself. The amino acid sequences can either be identical for each subunit, or similar (as in $\alpha$ and $\beta$ chains of hemoglobin). The assembly of many identical subunits provides a very efficient way of constructing large structures such as bacterial coats. Often a multisubunit molecule is more smoothly globular than its component subunits.

Colored stained antigen was prepared (Photo 3). The total protein concentrations of stained subunit flagellar and somatic antigens were adjusted to $6.4 \mathrm{ng} / \mu \mathrm{l}$ with the help of standard curve at this level can aid in efficient.

There is a need for specific diagnosis of bacterial diseases due to a number of bacteria produce a similar syndrome, generically referred to as hemorrhagic septicemia and characterized by external reddening and hemorrhage in the peritoneum, body wall, and viscera. Morbidity and mortality are highly variable, depending on predisposing conditions such as low dissolved oxygen, other water quality problems, handling stress, or trauma. Ulcerative lesions are common as disease progresses, and mortality can be significant if stress is not controlled Zorrilla et al., (2003).

The serum collected after the artificial inoculation of experimented fish was examined against stained antigen by slide microagglutination test. The serum was having different immune titer due to it was collected at wide range time and it was giving good indication about the ability of this sainted antigen to be diagnosed the A. hydrophila infection and the ability was related to the produced immune level (Table 5). The antibody titer was suitable for agglutination process and can be detected the infection even at low level and same results was recorded by Roberts, (1989) who cited there is no agglutination can be observed when the concentration of antibody is high, (lower dilutions), and then the sample is diluted, agglutination occurs. Prozone effect is defined as the invisibility of agglutination at high concentrations of antibodies. It is due to the 
reason that excess antibody forms very minute complexes that do not clump to form visible agglutination.

Methods of detecting quantitative antigen or antibody take advantage of the fact that they react to form a complex. At the optimum antigen-antibody concentration, this complex precipitate out. However, if the antigen is particulate in nature, agglutination of antigen-antibody complex is observed (Roberts, 1989).

The reaction between a particulate antigen and an antibody results in visible clumping called agglutination. Antibodies that produce such reactions are known as agglutinins. The principle of Agglutination reaction is similar to precipitation reactions; they depend on the cross linking of polyvalent antigens. When the antigen is an erythrocyte it is called hemagglutination. Theoretically all antibodies can agglutinate particulate antigens (Pridgeon and Klesius 2011).

The examined serum samples from artificial infected fish with $A$. hydrophila, experimentally induced, reacted strongly in the latex test (Photo, 4). Moreover, serum from healthy fish showed negative. In addition to permitting rapid and accurate diagnosis of A. hydrophila. The sensitivity and specificity of the method were found to be $90 \%$, $77.5 \%$ (Table 6) in case of somatic antigen and $92.5 \% 72.5 \%$ in case of flagellar antigen respectively (Table 7). The Sensitivity and specificity gave an idea about the good efficiency of the stained antigen to diagnosis the disease and that similar with that recorded by (Kachigan, 1991) who cited sensitivity and specificity describe how well the test discriminates between variables with and without disease. They address a different question than want answered when evaluating variables.

Common bacterial isolates from affected fish include Aeromonas and Pseudomonas sp., which are more common in freshwater animals, and Vibrio sp., more commonly isolated from marine fishes. Control is based on quick removal of predisposing factors by rapid field diagnosis.

It can be concluded that using of established latex can be easy applied as agglutination test in field diagnosis of some bacterial fish. 
Table (2). Mortality rate of experimentally infected fish with isolated strain of A.hydrophila

\begin{tabular}{cccc}
\hline Group & Total No. & No of dead & Mortality rate \\
\hline G1 & 100 & 60 & $60 \%$ \\
G2 & 100 & 5 & $5 \%$ \\
\hline
\end{tabular}

G1 injected with isolated strain of A.hydrophila

G2 (Control) injected with sterile saline

Table (3). Number of dead fish per day during the first week post inoculation

\begin{tabular}{cccccccc}
\hline Days post inoculation & $\mathbf{1}^{\text {st }}$ & $\mathbf{2}^{\text {nd }}$ & $\mathbf{3}^{\text {rd }}$ & $\mathbf{4}^{\text {th }}$ & $\mathbf{5}^{\text {th }}$ & $\mathbf{6}^{\text {th }}$ & $\mathbf{7}^{\text {th }}$ \\
\hline G1 & 7 & 30 & 15 & 5 & 3 & - & - \\
G2 & 3 & 2 & - & - & - & - & - \\
\hline
\end{tabular}

G1 injected with isolated strain of A.hydrophila

G2 (Control) injected with sterile saline

Table (4). Antibodies titers measured by hemagglutination inhibition test

\begin{tabular}{cccc}
\hline Time & $\mathbf{7}$ days & 14 days & 21 days \\
\hline Antibody titer & 8 & 32 & 128 \\
\hline
\end{tabular}

Table (5). Examination of stained antigens against different levels of prepared specific antibodies

\begin{tabular}{cccc}
\hline Antibody titer & $\mathbf{8}$ & $\mathbf{3 2}$ & $\mathbf{1 2 8}$ \\
\hline $\begin{array}{c}\text { Agglutination by stained } \\
\text { Ag }\end{array}$ & $91 \%$ & $94 \%$ & $96 \%$ \\
\hline
\end{tabular}


Table (6). Sensitivity and specificity of slide agglutination for somatic antigen of A.hydrophila

\begin{tabular}{lllll}
\hline & G1 & G2 & Sensitivity & Specificity \\
\hline Positive & 36 & 9 & & \\
Negative & 4 & 31 & $90 \%$ & $77.5 \%$ \\
Total No. & 40 & 40 & & \\
\hline
\end{tabular}

Table (7). Sensitivity and specificity of slide agglutination test for flagellar antigen of A.hydrophila

\begin{tabular}{lllll}
\hline & G1 & G2 & Sensitivity & Specificity \\
\hline Positive & 37 & 11 & & \\
Negative & 3 & 29 & $92.5 \%$ & $72.5 \%$ \\
Total No. & 40 & 40 & & \\
\hline
\end{tabular}

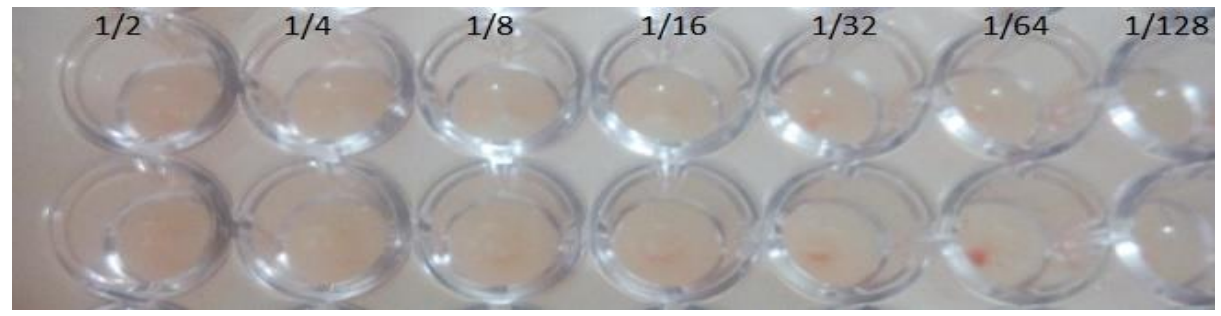

Photo. (1). Hemagglutination activity of isolated A. hydrophila.

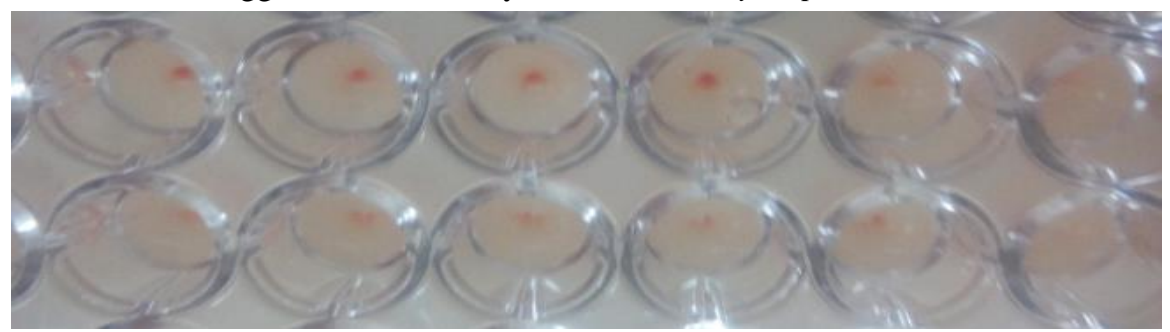

Photo. (2). Hemagglutination inhibition activity of serum collected from artificial infected tilapia. 
Photo. (3). Stained colored antigen of locally isolated A. hydrophila.

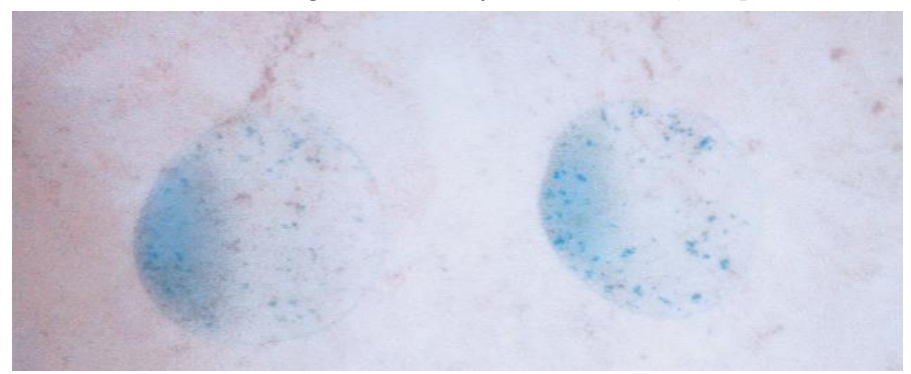

Photo. (4). Slide agglutination test showing strong react of A.hydrophila colored stained antigen with serum samples of experimentally infected fish.

\section{References}

Ariel, E. and Owens, L., (1997). Epizootic mortalities in tilapia Oreochromis mossambicus. Dis. Aquat. Org. 29, 1-6.

Austin, B. and Austin, D. A. (1987): Bacterial fish pathogens: disease in farmed and wild fish. Ellis Horwood Limited, Chichester, England.

Evans, J. J.; Klesius. P.H. and Shoemaker, C.A. (2004). Efficacy of Streptococcus agalactiae (group B) vaccine in tilapia (Oreochromisniloticus) by intraperitoneal and bath immersion administration. Vaccine 22:3769-3773.

Idowu, T.A.; Onyia, L.U and Kefas, M. (2017). Fish diseases and health management. In: Contextual aquaculture and fisheries digest. Maiden Edition. Paraclete Publisher 155-171.

Kachigan, S. (1991). Statistical Analysis: A conceptual introduction, Radius Press., 8: (16). 
Lowry, O. H.; Rosebrough, N. J.; Farr, A. L. and Randall, R. J. (1951). Protein measurement with the Folin phenol reagent. J. Biol. Chem. 193, 265-275.

Luky, S. (1977). Methods for the diagnosis of fish disease Amerind publishing co.ltd., new Delhy.,Bombay,Calcutta and New York.

McGraw, H. (1957). Manual of Microbial Methods. Proc. R. Soc., London B. Chapter 9: 206-209.

Otte, E. (1963). Die heutigen Anchten uber-die atiologie der infektiosen bachwasser sucht der karpfen. Weiener Tieraztliche monatsshrift 50; 995-1005.

Post, G. W. (1989). Text book of fish health J. F. H publication, Inc Ltd. 211 West Syvania Avenue Neptune city NJ 00753.

Pridgeon, J.W. and Klesius, P.H. (2011). Development and efficacy of novobiocin and rifampicin-resistant Aeromonas hydrophila as novel vaccines in channel catfish and Nile tilapia. Vaccine 29, 7896-7904.

Roberts, R.J. (1989). Fish pathology $2^{\text {nd }}$ edition., Balliere Tindall, London, PP; 295-310.

Sahu, S.; Das, B.K.; Mishra, B. K.; Pradhan, J. and Sarangi, N. (2007). Effect of Allium sativum on the immunity and survival of Labeo rohita infected with Aeromonas hydrophila. Journal Applied Ichthyology, 23: 80-86

Zorrilla, I. M.; Chbrillon, M. S.; Diaz-Rosales, M.; MartinzManzanares, M.C. and Marinigo, M. A. (2003). Bacterial recovered from diseased cultured gilhead sea bream (Sparus aurata L.) in southeastern Spain. Aquaculture 218: 112. 


\section{كفاءة اختبار التخثر في تثخيص مرض التسمم الدموى الإيروموناسى فى

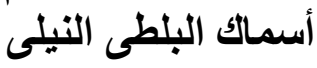

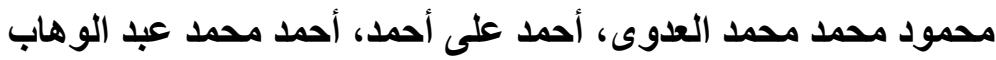

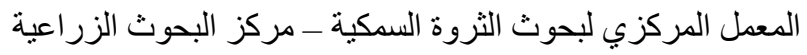

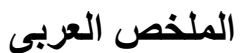

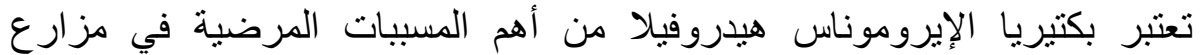

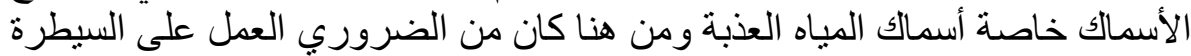

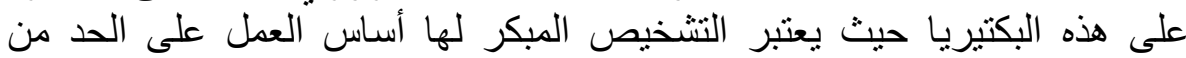

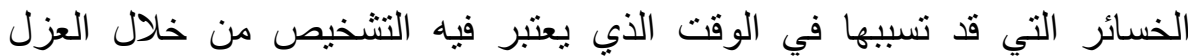

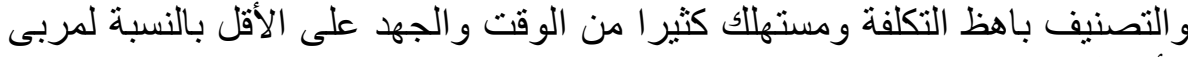
الأسماك.

ومن هنا كان الهدف من هذه الدراسة هو عمل كاشفات بسبطة من السهل أن تستخدم

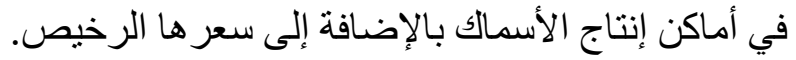

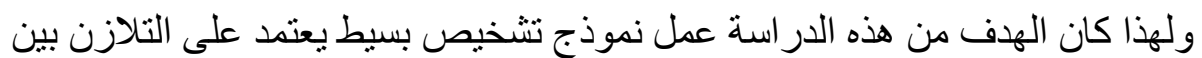

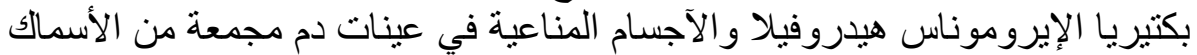

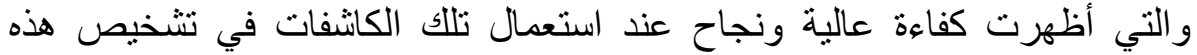

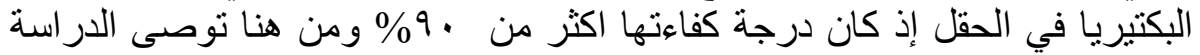

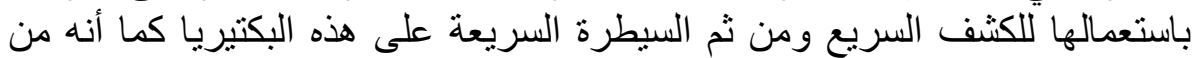

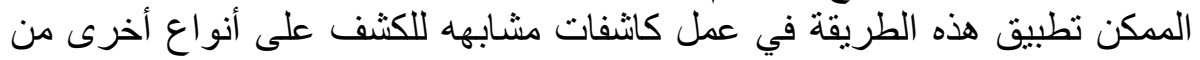
البكتيريا. 